\title{
Voor-bode (2015) bevestig Cas Vos se konsekwente bydrae tot die Afrikaanse poësie
}

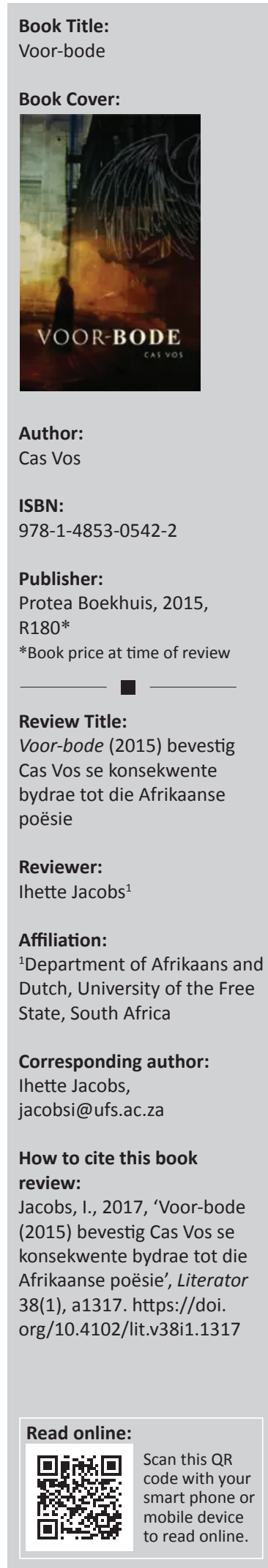

Voor-bode (2015) is die afgetrede teoloog Cas Vos se negende digbundel, uitgesluit twee bundels wat in Engels vertaal is. Dié negende toevoeging tot die Afrikaanse poësie getuig van 'n skrywershand wat reeds agt goed ontvangde bundels op sy kerfstok het en wat konsekwent diepgaande en struktureel verfynde poësie lewer.

Die bundeltitel word op 'n ongewone wyse met 'n koppelteken geskryf. Dié titel vereis dat die leser met die eerste oogopslag weet dat nie alleen die betekenis van die woord voorbode ter sprake gaan kom nie, maar ook die individuele konsepte voor en bode. Die oorspronklike betekenis van die woord voorbode word deur die HAT (2000:1315) omskryf as 'Voorteken, dikwels van bonatuurlike aard; onverklaarbare boodskap dat iets gaan gebeur, kom'. Alhoewel 'n voorbode dikwels aan onheil gekoppel word, is dit nie noodwendig 'n gegewe nie; 'n voorbode kan ook 'n positiewe teken wees. Die betekenisvolle verband tussen voorbode en voorteken is opvallend vanweë die suggestie dat 'n bode sterk verband hou met 'n teken. Hier kan teken verstaan word in 'n semiotiese sin, en kan die titel onder meer gelees word as die tekens wat vooraf kom in die vorm van bodes. Twee vrae ontstaan hieruit, naamlik waarvan is hierdie tekens ' $n$ aanduiding en wat is die aard van die bodes wat die tekens moet oordra.

Om die eerste vraag te beantwoord, kan die leser let op die bundelstruktuur; op sigself interessant, is dit onderverdeel in die volgende afdelings: (1) Eerste woorde, (2) Eerstelinge, (3) Bodes, (4) Liefdesbodes, (5) Voorlopers, (6) Pyngesante en (7) Volheid. Die progressie wat dié titels illustreer, sowel as die hoeveelheid afdelings is veelseggend. Sewe is immers 'n betekenisvolle getal in onder meer die Chinese kultuur en die Christendom. Laasgenoemde is meer relevant tot die bundel, omdat daar heelwat ander Bybelse verwysings in Voor-bode gevind kan word. In die Bybelse konteks verwys sewe na spirituele heelheid en heiligheid, wat eenheidskeppend aansluit by die titel van die laaste afdeling, 'Volheid'. Hieruit kan afgelei word dat die tekens/bodes die bereiking van 'volheid' voorafgaan. Die progressie in die bundel en die woordspel wat deur onder meer die bundeltitel daargestel word, groei tot die volheid wat in die sewende afdeling 'onverhoeds verras' (bl. 125). Die bundel beeld nie alleen strukturele progressie uit nie, maar tesame met die tematiese ontwikkeling en 'n dikwels chronologiese narratief, word 'n hegte en betekenisvolle bundelinhoud moontlik gemaak.

Die tweede vraag wat hierbo gestel is, hou verband met die aard van die bodes wat in Voor-bode funksioneer. Net soos wat 'n taalteken ryk aan implikasie en betekenis is, is die bodes - en die tekens wat hulle verteenwoordig - ook in die bundel veelvuldig. Daar is die konkrete boodskappers, soos die engele en die skrywers wat die outeur voorafgaan, maar dan is daar ook die liefde, die lig en die donker wat bodes kan wees. In 'n breër sin is elke gedig 'n bode, wat betekenis aan die leser wil oordra. Neem byvoorbeeld 'Oersprong' (bl. 11), wat sinspeel op die 'oorsprong' van die woord as boodskapper:

Woorde spruit uit onsigbare plekke: uit die vlugvoet van katte, die skel blaf van honde, die asemhaling van voëls.

Woorde kom uit die afgronde van die gees waar'n vreemde en duister lewe in beroering is, en hallusinasies, versinsels en denke dwaal.

Onsigbaar versmelt woorde spitsvondig in

stilte tot letters voelbaar spelerig

en verlig oor die lip van die donker gly. 
'Voor-bode' as titelgedig, funksioneer ook as 'n opdraggedig waarmee die bundel open en wat die belangrike bundeltema van dag teenoor nag, en lig teenoor donker - asook die simboliese moontlikhede van hierdie teenstellings - reeds uit die staanspoor beklemtoon:

Môrester, oog van die daeraad, kyk

deur die donker se naat waar duister

soos 'n vlermuis vlug voor die nag

hom verlaat.

Dualisme vorm deurgaans die tematiese onderbou van Voorbode. So funksioneer die aanvang van dinge (veral in die afdeling 'Eerstelinge') as belangrike tema, maar dit kom nie voor sonder die duidelike bewustheid van die dood nie (verwys byvoorbeeld na 'Vervloek is my geboorte', bl. 19).

Hierdie tematiese teenstelling word verder uitgebeeld deur die intertekstuele Bybelse narratief wat deur die volgende gedigtitels uit II Eerstelinge geillustreer word: 'Maria van Nasaret' (bl. 21), 'Kersfees' (bl. 23-24), 'Getsemane' (bl. 25), 'Die nag van Golgota' (bl. 27), 'Afslaer' (bl. 29), 'Emmausgangers: 'n Portret' (bl. 30). Dit is opvallend dat hier beweeg word vanaf lewe (Maria se swangerskap en Jesus se geboorte) na dood (kruisiging) en dan weer na lewe (die opstanding wat deur Jesus se verskyning aan sy volgelinge in laasgenoemde gedig uitgebeeld word).

Voor-bode is ryk aan intertekstuele en intratekstuele verbande. Eersgenoemde vind uitdrukking in onder meer die talle gesprekke wat aangegaan word met Bybelse narratiewe, figure en uitdrukkings, maar ook literêre skrywers wat die outeur voorafgaan ('Voor-skrywers', bl. 61), RoomsKatolieke heiliges ('Franciscus van Assisi', bl. 65 en 'Melankolie', bl. 70), die liefdesbriewe wat kunstenaars aan hulle geliefdes skryf ('Wolfgang Amadeus Mozart aan Constanze', bl. 51-52 en 'John Keats aan Fanny Brawne, $1820^{\prime}$, bl. 53-54) en eietydse gebeure in die Suid-Afrikaanse historiese konteks ('Marikana', bl. 102-103 en "n Man is dood', bl. 104). Daar is ook gedigte van persoonlike aard, dikwels gerig aan die geliefde. Vertalings van die gedigte van Konstantinos P. Kavafis en Giorgos Seferis beslaan 'n groot gedeelte van die bundel. Die vaardigheid waarmee die gedigte vertaal is, is beeldend van Vos se besondere taal- en poësie-aanvoeling, maar die vertalings - dalk vanweë die feit dat hulle deur die bundel versprei is - laat die outeur se eie gedigte soms onnodig afsteek.

Intratekstuele verbande kom meer geslaagd voor in die vorm van gesprekke tussen gedigte, byvoorbeeld tussen 'Drie donker nagte' (bl. 14-15) en 'Nag van vlees' (bl. 18), maar minder geslaagd is die oormatige herhaling van motiewe wat die subtiliteit van die eenheidvorming in die bundel bedreig.

Voor-bode is 'n bundel wat maklik lees, wat die poësieleser wat op soek is na ontspanning en die estetiese tevrede stel, hoewel daar ook uitdagings versteek lê in die spel van woorde en tekens, vir diegene wat daarna gaan soek.

\section{Literatuurverwysings}

Odendal, FF. \& Gouws. R.H., 2000, HAT: Verklarende handwoordeboek van die Afrikaanse taal, 4de uitg., pp. xx-1386, Perskor, Johannesburg. 